
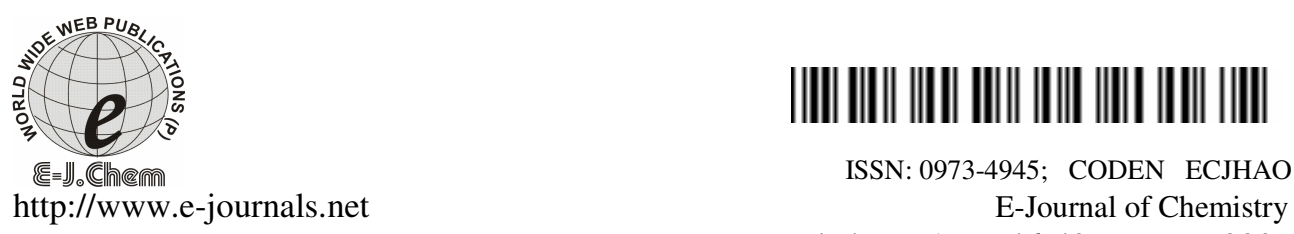

Vol. 4, No.1, pp 46-49, January 2007

\title{
Extractive Spectrophotometric Methods for the Determination of Rosuvastatin Calcium in Pure Form and in Pharmaceutical Formulations by Using Safranin $O$ and Methylene blue
}

\author{
MAROTHU VAMSI KRISHNA and DANNANA GOWRI SANKAR* \\ Pharmaceutical Analysis and Quality Assurance Division, \\ Department of Pharmaceutical Sciences, \\ Andhra University, Visakhapatnam, India. \\ E-mail:marothu_vamsi@rediffmail.com
}

Received 1 August 2006; Accepted 9 September 2006

\begin{abstract}
Two simple extractive Spectrophotometric methods are described for the determination of rosuvastatin calcium (RST) in pure form and in pharmaceutical formulations. These methods are based on the formation of ion association complexes of the RST with basic dyes safranin $\mathrm{O}($ Method A) and methylene blue (Method B) in basic buffer of $\mathrm{pH} 9.8$ followed by their extraction in chloroform. The absorbance of the chloroform layer for each method was measured at its appropriate $\lambda_{\max }$ against the reagent blank. These methods have been statistically evaluated and are found to be precise and accurate.
\end{abstract}

Keywords: Rosuvastatin calcium, Extractive Spectrophotometry, Determination.

\section{Introduction}

Rosuvastatin calcium (RST) is an anti hyperlipidimic agent and is chemically known as 6heptenoic acid, 7-[4-((4-fluorophenyl)-6-(1-methylethyl)-2-[methyl (methylsulphonyl) amino]-5-pyrimidinyl]-3, 5-dihydroxy-, calcium salt (2:1), (3R, 5S, 6E). It acts by inhibiting the enzyme 3-hydroxy-3-methyl glutaryl- coenzyme A (HMG-coA) reductase.To the best of our knowledge, there is no work in the literature reported about the visible spectrophotometric methods for the quantification of RST in pure drug and in pharmaceutical formulations, however one HPTLC ${ }^{1}$ and few LC-MS ${ }^{2-4}$ methods have been reported for the estimation of RST in pharmaceutical preparations and in biological fluids. The proposed methods are based on the formation of ion association complexes of the RST 
with basic dyes safranin O (SFN O) and methylene blue (MTB) in basic buffer of pH 9.8 followed by their extraction in chloroform.

\section{Experimental}

\section{Apparatus}

All spectral and absorbance measurements were made on a systronic model 106 digital spectrophotometer with $10 \mathrm{~mm}$ matched quartz cells.

\section{Materials and reagents}

All chemicals used were of analytical reagent grade. RST was obtained from Dr.Reddy's labs Hyderabad. Fortius, Rostar and Novostat are the commercial tablet formulations labeled to contain 5, 10 and $20 \mathrm{mg}$ of RST per tablet respectively.SFN O $(0.2 \% \mathrm{w} / \mathrm{v})$ solution was prepared by dissolving $200 \mathrm{mg}$ of Safranin O in $100 \mathrm{ml}$ of distilled water.MTB $(0.2 \% \mathrm{w} / \mathrm{v})$ solution was prepared by dissolving $200 \mathrm{mg}$ of Methylene blue in $100 \mathrm{ml}$ of distilled water. Ammonia- ammonium chloride buffer solution ( $\mathrm{pH} 9.8$ ) was prepared by mixing $7 \mathrm{~g}$ of ammonium chloride with $56.8 \mathrm{ml}$ of liquor ammonia solution and diluted to $100 \mathrm{ml}$ with distilled water and $\mathrm{pH}$ was adjusted to 9.8 .

Standard solution of RST $(1 \mathrm{mg} / \mathrm{ml})$ was prepared by dissolving $100 \mathrm{mg}$ of drug in 100 $\mathrm{ml}$ of methanol. It was further diluted with methanol to get the working standard solution of $50 \mu \mathrm{g} / \mathrm{ml}$.

\section{General procedure and calibration}

Different aliquots of standard solution $(50 \mu \mathrm{g} / \mathrm{ml}$ ) from $1.0-5.0 \mathrm{ml}$ (for method A) or 0.5 $2.5 \mathrm{ml}$ (for method $\mathrm{B}$ ) and $1.0 \mathrm{ml}$ of $\mathrm{pH} 9.8$ buffer solutions were placed separately in a series of $125 \mathrm{ml}$ separating funnels. A volume of $1.5 \mathrm{ml}$ of SFN O for method A or $0.5 \mathrm{ml}$ of MTB for method B was added respectively. The total volume in each funnel was adjusted to $10 \mathrm{ml}$ with distilled water. Then $10 \mathrm{ml}$ of chloroform was added to each separating funnel and the contents were shaken for 2 minutes and allowed to separate. The organic layer was collected through cotton plug and the absorbance was measured immediately at $530 \mathrm{~nm}$ for method A and at $655 \mathrm{~nm}$ for method B against the reagent blank. Both the colored species were stable for 2 hours. The calibration graph was then prepared by plotting the absorbance versus concentration of the drug. The concentration of the unknown was read from the calibration graph or computed from the regression equation.

\section{Procedure for tablets}

Twenty tablets were weighed accurately and ground in to a fine powder. An amount of powder equivalent to $100 \mathrm{mg}$ of RST was weighed into a $100 \mathrm{ml}$ volumetric flask, $50 \mathrm{ml}$ of the methanol was added and shaken thoroughly for about $10 \mathrm{~min}$, then the volume was made up to the mark with the methanol, mixed well and filtered using a quantitative filter paper. The assay of the tablets was completed according to the general procedure.

\section{Results and Discussion}

Optical characteristics such as Sandell's sensitivity, molar absorptivity, precision and accuracy were found by performing eight replicate determinations containing $3 / 4^{\text {th }}$ of the amount of the upper beer's law limits. The measured standard deviation (S.D.), Relative standard deviation (RSD), and confidence limits can be considered satisfactory for both the methods and are summarizes in Table 1. Pharmaceutical formulations of RST were successfully analyzed by the proposed and the reference methods. The results obtained by 
proposed and reference methods are presented in Table 2 . To evaluate the validity and reproducibility of the methods, known amounts of pure drug were added to the previously analyzed samples and the mixtures were analyzed by the proposed methods. The ingredients present in the formulations of RST did not interfere with the proposed analytical methods. In conclusion the proposed extractive spectrohotometric methods for the estimation of RST are simple, sensitive, accurate and useful for routine quality control analysis.

Table1. Optical and regression characteristics, precision and accuracy of the proposed methods for RST

\begin{tabular}{lcc}
\hline \multicolumn{1}{c}{ Parameter } & Method A & Method B \\
\hline$\lambda_{\max }(\mathrm{nm})$ & 530 & 655 \\
Beer's law limits $\left(\mu \mathrm{g} \mathrm{ml}^{-1}\right)$ & $5.0-25.0$ & $2.5-12.5$ \\
Detection limits $\left(\mu \mathrm{g} \mathrm{ml}^{-1}\right)$ & 0.099 & 0.076 \\
Molar absorptivity $\left(\mathrm{L} \mathrm{mole}^{-1} \mathrm{~cm}^{-1}\right)$ & $3.60 \times 10^{4}$ & $6.54 \times 10^{4}$ \\
Sandell's sensitivity & 0.027 & 0.015 \\
$\left(\mu \mathrm{g} \mathrm{cm}^{-2} / 0.001\right.$ absorbance unit$)$ & & \\
Optimum photometric range $\left(\mu \mathrm{g} \mathrm{ml}^{-1}\right)$ & $6.0-23.0$ & $3.5-10.5$ \\
Regression equation $(\mathrm{Y}=\mathrm{a}+\mathrm{bC})$ & & \\
Slope $(\mathrm{b})$ & $3.61 \times 10^{-2}$ & $6.52 \times 10^{-2}$ \\
Standard deviation of slope $\left(\mathrm{S}_{\mathrm{b}}\right)$ & $0.70 \times 10^{-4}$ & $2.00 \times 10^{-4}$ \\
Intercept (a) & $-3.00 \times 10^{-4}$ & $1.40 \times 10^{-3}$ \\
Standard deviation of intercept $\left(\mathrm{S}_{\mathrm{a}}\right)$ & $1.20 \times 10^{-3}$ & $1.67 \times 10^{-3}$ \\
Standard error of estimation $\left(\mathrm{S}_{\mathrm{e}}\right)$ & $1.14 \times 10^{-3}$ & $1.59 \times 10^{-3}$ \\
Correlation coefficient $(\mathrm{r})$ & 0.9999 & 0.9999 \\
Relative standard deviation $(\%) *$ & 0.172 & 0.108 \\
$\%$ Range of error $($ Confidence limits)* & & \\
0.05 level & 0.144 & 0.090 \\
0.01 level & 0.213 & 0.134 \\
$\%$ Error in bulk samples** & -0.260 & 0.038 \\
\hline
\end{tabular}

*Average of eight determinations

** Average of three determinations

In $\mathrm{Y}=\mathrm{a}+\mathrm{bC}, \mathrm{Y}$ is absorbance and $\mathrm{C}$ is concentration.

Table2. Results of analysis of tablet formulations containing RST

\begin{tabular}{ccccc}
\hline Method & Formulations & $\begin{array}{c}\text { Labeled } \\
\text { amount } \\
(\mathrm{mg})\end{array}$ & \% Recovery ${ }^{\text {a }}$ & $\begin{array}{c}\text { \% recovery } \\
\text { of reference } \\
\text { method }^{\text {b }}\end{array}$ \\
\hline \multirow{3}{*}{$\mathrm{A}$} & Fortius & 5 & 99.95 & 99.98 \\
& Rostar & 10 & 100.00 & 100.35 \\
& Novostat & 20 & 100.08 & 100.10 \\
B & Fortius & 5 & 100.05 & 99.98 \\
& Rostar & 10 & 100.15 & 100.35 \\
\hline
\end{tabular}

${ }^{\mathrm{a}}$ Average of six determinations $\quad{ }^{\mathrm{b}} \mathrm{UV}$ method developed in our laboratory. 


\section{References}

1 SaneR T, Kamat S S, Menon S N, Inamdar, Shafi R, and Mander R. J. planar chromatography-Modern TLC. 2005, 18, 194.

2 Kathalijne A, Oudhoff, Timothy Sangster, Elizabeth Thomas, Ian D and Wilson.

J. Chromatogr. B. 2006, 832, 191.

3 Ravi Kumar T, Raja Reddy K, Ramesh M and Srinivas R. J. Pharm. Biomed. Anal.2005, 39, 661.

4 Hull C K, Penman A D, Smith C K and Martin P D. J. Chromatography B: Analytical Technologies in the Biomedical and Life Sciences.2002, 772, 219. 


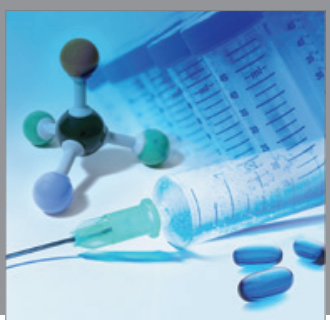

International Journal of

Medicinal Chemistry

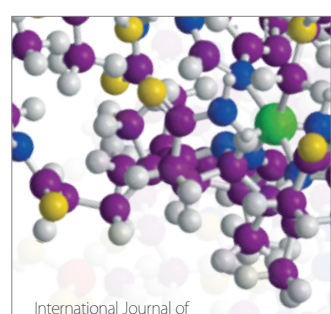

Carbohydrate Chemistry

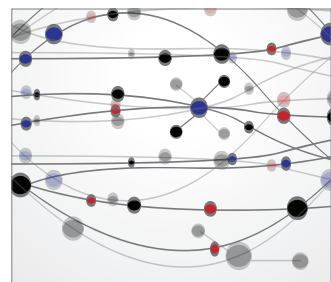

The Scientific World Journal
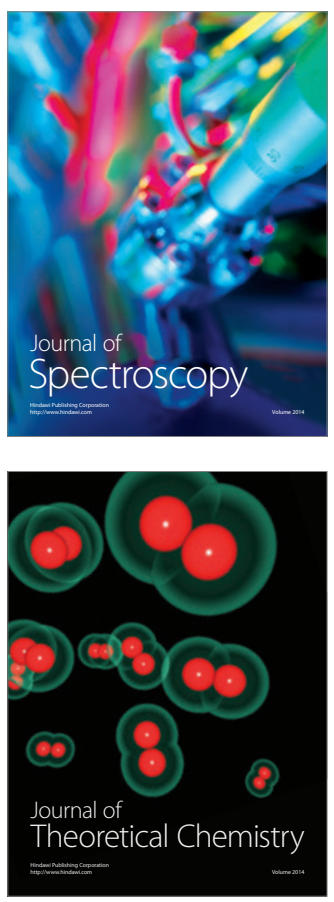
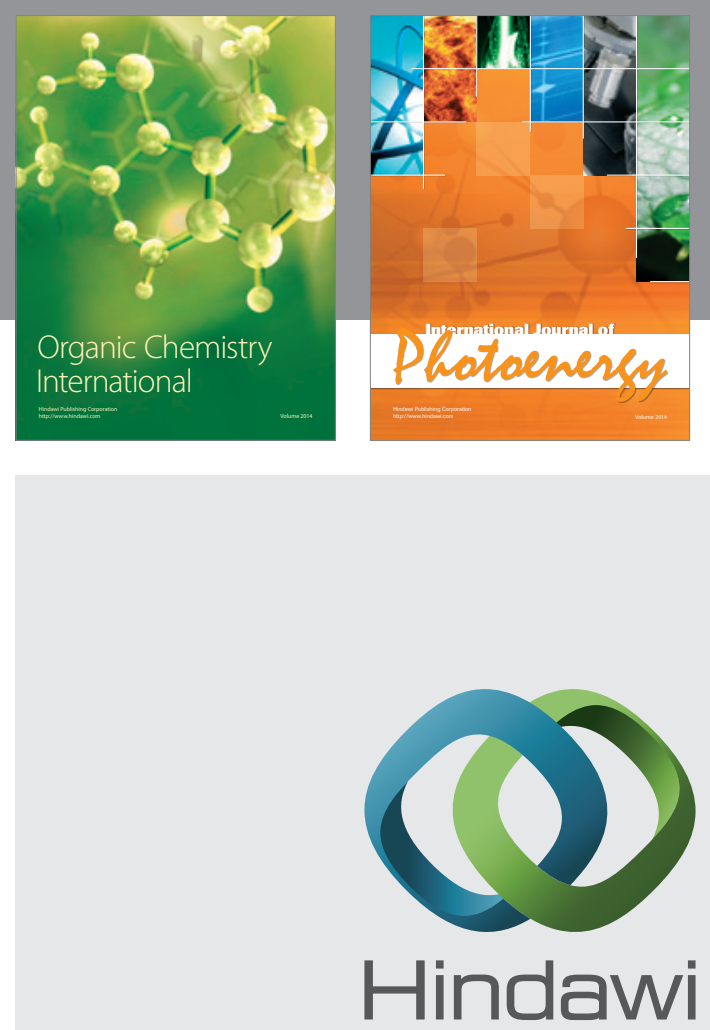

Submit your manuscripts at

http://www.hindawi.com
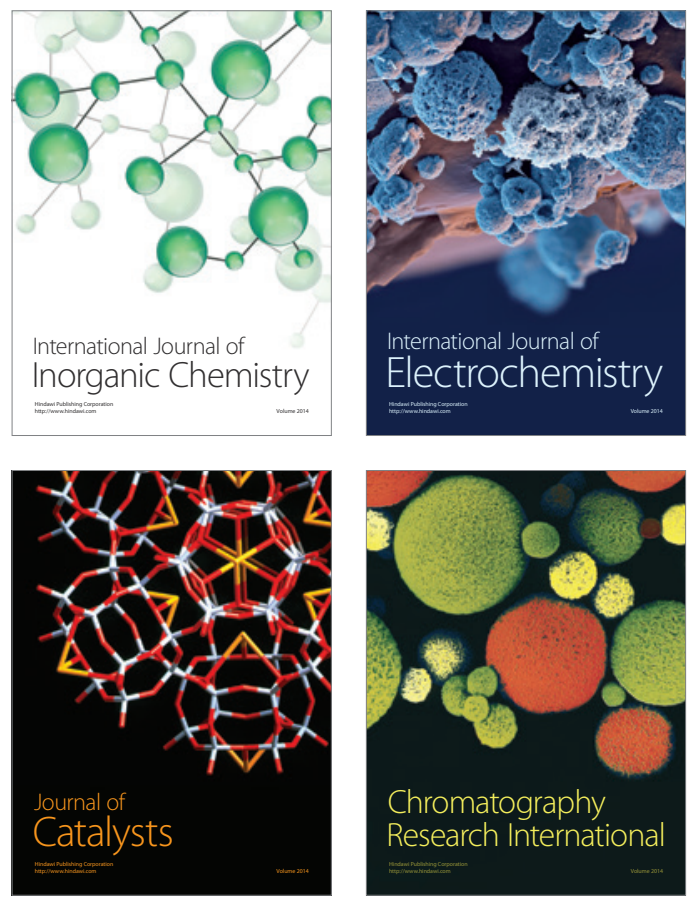
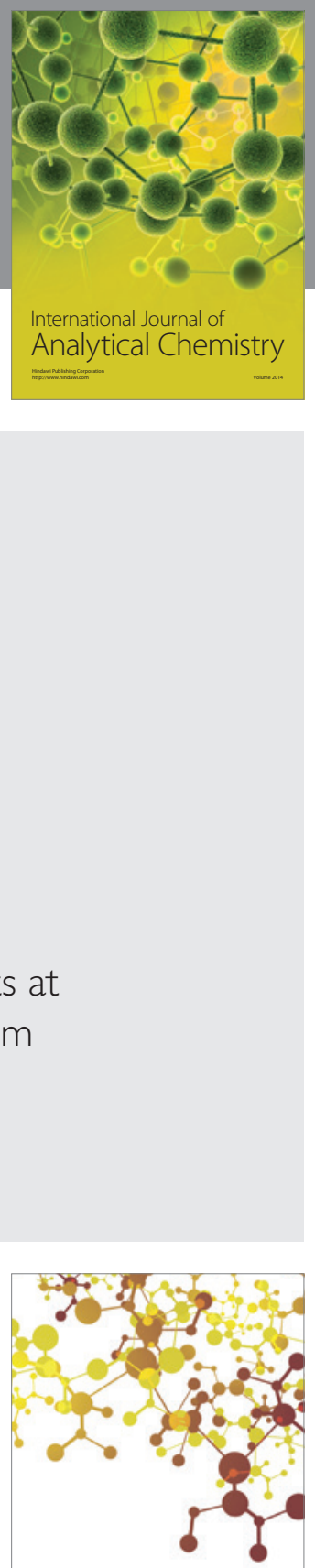

Journal of

Applied Chemistry
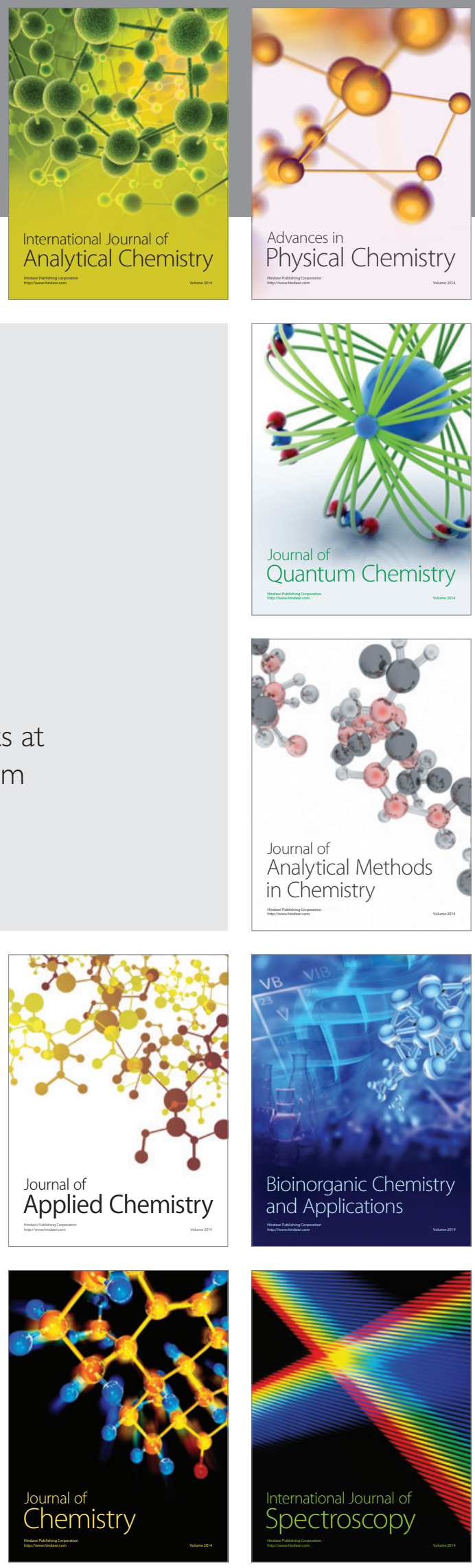